\title{
Discusión del artículo "Injerto libre braquial medial"
}

\author{
Discussion of the article "Free medial arm graft"
}

Los autores describen un caso bien resuelto desde un punto de vista reconstructivo, con un injerto libre braquial medial (ILBM), y les llama la atención que un colgajo con muchas ventajas para la reconstrucción de cabeza y cuello, en la práctica diaria se utilice $\tan$ poco.

Hay que comentar que el injerto antebraquial ha sido en algunos servicios y sigue siendo en otros, el caballo de batalla en la cirugía reconstructiva de cabeza y cuello para defectos de partes blandas. Es indiscutible que reúne muchas cualidades como: anatomía constante, longitud y diámetro del pedículo ideal, piel fina, simplicidad técnica. Pero también tiene algunos inconvenientes importantes como: deja la vascularización de la mano dependiente únicamente de la arteria cubital, la cicatriz de la zona donante en el mejor de los casos es inestética y en el peor puede ser dramática cuando hay pérdida del injerto libre de piel o hay exposición de los tendones palmares. Asimismo es frecuente, aunque no obligada la pérdida de sensibilidad en la zona del pulgar que resulta incomoda para el paciente. Todo ello hace que a pesar de que seguramente haya sido el colgajo más utilizado en todo el mundo hay que buscar alternativas con menor morbilidad.

Felicitamos a los autores por ese intento de buscar sustituto al injerto antebraquial. El problema es, si verdaderamente $¿$ el injerto libre braquial medial es la solución ideal para la reconstrucción de partes blandas en cabeza y cuello? y por otro lado, hay que ver si ¿existen otras alternativas?

A la primera cuestión, parece que no es la solución ideal, dado que tiene inconvenientes importantes desde el punto de vista técnico: pedículo corto y de diámetro muy desigual a los vasos receptores del cuello, anatomía variable, técnica de disección por tanto más compleja. Por otro lado, la disponibilidad de tejido es limitada. De cualquier modo estamos totalmente de acuerdo con los autores cuando dicen en las conclusiones, que el ILBM es una opción más a la hora de la reconstrucción de defectos a nivel de cabeza y cuello.

A la segunda pregunta nuestra opinión es, que sí existen otras alternativas. Nos gustaría mencionar como una de ellas el injerto libre braquial lateral muy similar en casi todo al ILBM. Lo hemos utilizado en cuatro ocasiones para el cierre de fístulas faringocutáne-

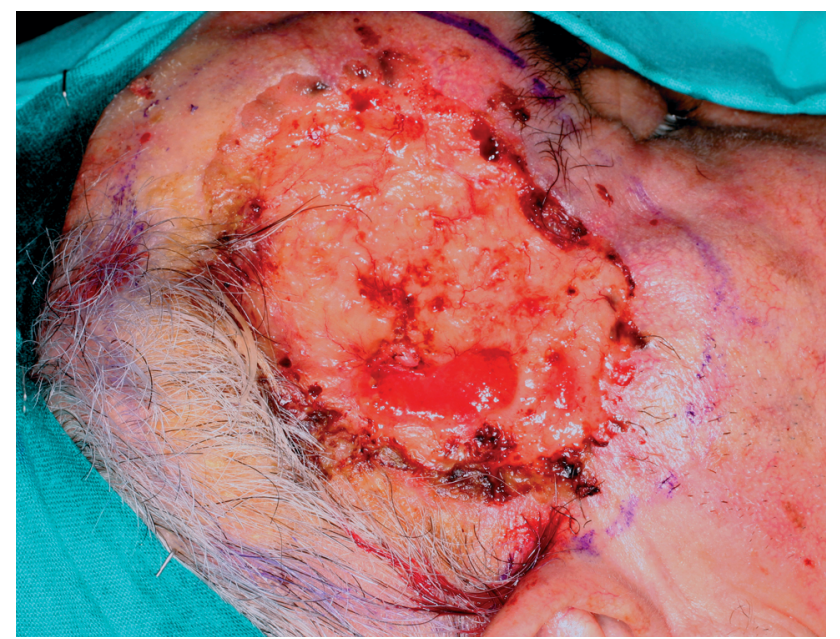

Figura 1. Lesión en la piel de la región temporal. Figure 1. Lesión in the temporal skin area.
The authors describe a case that resolved well, from a reconstructive vantage point, using a free medial arm graft (FMAG). They note that although this flap offers many advantages for the reconstruction of the head and neck, it is little used in daily practice.

It should be noted that the lower arm graft in some departments has been, and in other departments continues to be, the battle horse of reconstructive surgery of the head and neck for soft tissue defects. It unquestionably has many good qualities like consistent anatomy, ideal pedicle length and diameter, thin skin, and technical simplicity. It also has some important disadvantages, such as leaving the vascularization of the hand exclusively dependent on the ulnar artery, an unattractive scar in the donor zone in the best of cases and, in the worst, dramatic changes when the free skin graft is lost or palmar tendons are exposed. Loss of sensitivity in the thumb area is also common and uncomfortable for the patient, but it does not necessarily occur. Despite the fact that this is surely the flap that has been used most widely in the world, alternatives with less morbidity must be sought.

We congratulate the authors for trying to find a substitute for the lower arm graft. The problem is whether the free medial arm graft is the ideal solution for reconstructing the soft tissues of the head and neck and the other alternatives that may exist.

The answer to the first question is that it does not seem to be the ideal solution because there are important technical disadvantages: short pedicle, irregular diameter of the receptor vessels of the neck, variable anatomy, and the need for a more complex dissection technique. On the other hand, tissue availability is limited. In any case, we concur fully with what the authors say in the conclusions about FMAG being just another option for the reconstruction of the head and neck.

The answer to the second question is that, our opinion, 
as y reconstrucción de defectos de suelo de boca, en los que existía disponibilidad de la arteria facial. Pero aún sin negar las posibles indicaciones de estos injertos microvascularizados, en nuestra opinión, los colgajos de perforantes desplazarán al resto en la reconstrucción de defectos de partes blandas de cabeza y cuello como primera indicación. Las ventajas de estos son su baja morbilidad, posibilidad de efectuar un cierre directo, ausencia de limitación por las variaciones anatómicas, pedículo largo y buen diámetro del vaso. Los inconvenientes principales son la mayor dificultad técnica y el incremento del tiempo de intervención, pero que con la práctica pueden reducirse considerablemente.

Para ilustrar lo que decimos se muestra un caso clínico.

Varón de 64 años, sin antecedentes médicos de interés, que presentaba lesión de $7 \mathrm{~cm}$ de diámetro mayor, en región temporal dcha, con aspecto sangrante y ulcerado, con biopsia de epitelioma basocelular (Fig. 1).

Se realizó extirpación amplia de la lesión (Fig. 2) y reconstrucción del defecto con injerto anterolateral del muslo (Fig. 3).

El resultado postoperatorio a los 6 meses es excelente (Fig. 4).

Miguel Burgueño Servicio de Cirugía Oral y Maxilofacial. Hospital Universitario La Paz, Madrid. España

\section{Bibliografía}

1. Shyh-Jou Shieh, MD, Haw-Yen Chiu, Jui-Chin Yu, Shin-Chen Pan. Reconstruction of head and neck defects following cancer ablation. Plast Reconstr Surg 2000;105:2349.

2. Koshima I, Fukuda H, Yamamoto H, Moriguchi T, Soeda S, Ohta S. Free anterolateral thigh flaps for reconstruction of head and neck defects. Plast Reconstr Surg 1993;92:421.

3. Wei FC, Jain V, Ortho MC, y cols. Have we found an ideal soft-tissue flap? An experience with 672 anterolateral thigh flaps. Plast and Reconstr Surg 2002; 109:2219-26.

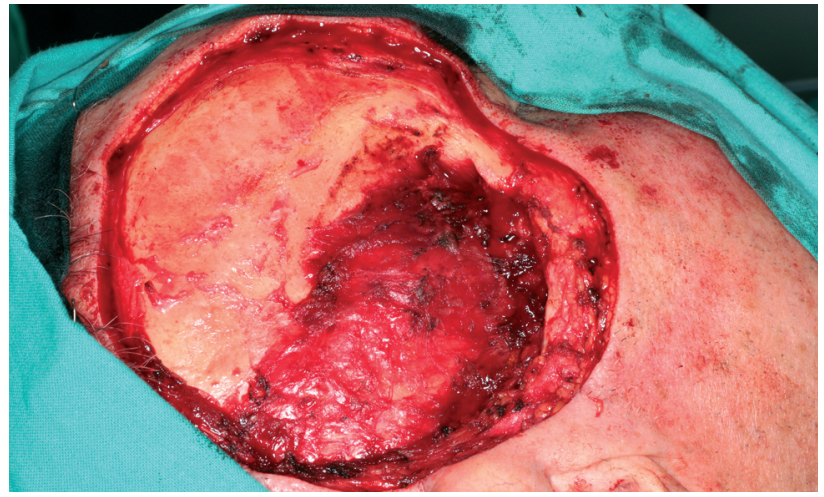

Figura 2. Defecto a reconstruir.

Figure 2. Defect to be reconstructed.

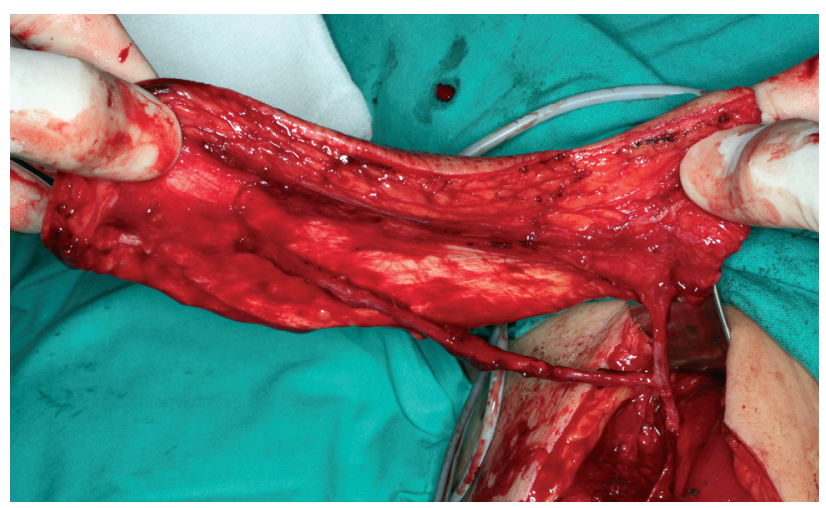

Figura 3. Elevación del colgajo.

Figure 3. Flap raise.

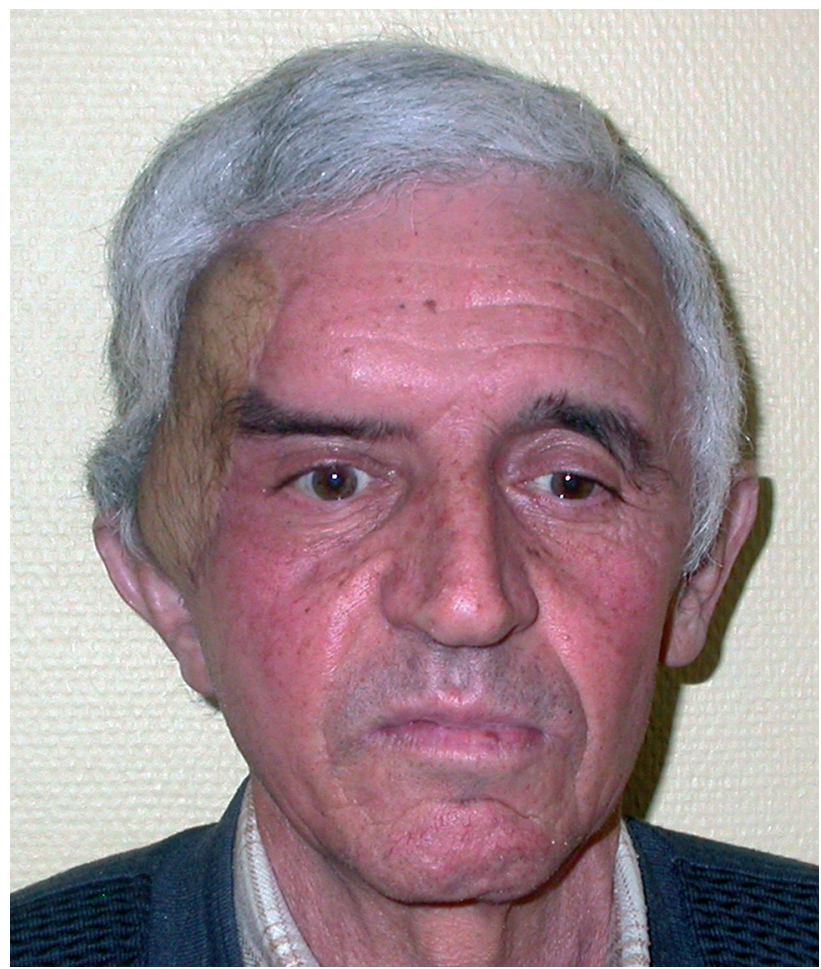

Figura 4. Resultado postoperatorio a los 6 meses. Figure 4. Final result after 6 months. there are other alternatives. We would like to mention that one of them, the free lateral arm graft, is similar in almost every way to FMAG. We have used it four times to close pharyngocutaneous fistulas and to reconstruct defects in the floor of the mouth when the facial artery is available. However, without denying the possible indications of these microvascularized grafts, in our opinion perforating vessel grafts set aside the rest in the reconstruction of soft tissue defects of the head and neck as the first indication. Their advantages are low morbidity, possibility to close directly, absence of limitations due to anatomic variations, long pedicle, and good vessel diameter. The main disadvantages are greater technical difficulty and increased operating time, but this improves considerably with practice.

We can illustrate this with a clinical case.

A 64-year-old man without a medical history of interest presented a lesion $7 \mathrm{~cm}$ in its largest diameter in the right temporal region, bleeding and an ulcerated appearance. Biopsy disclosed basal cell epithelioma (Fig. 1).

Enlarged excision of the lesion was performed (Fig. 2) with repair of the defect using an anterolateral thigh graft (Fig. 3).

The postoperative result at 6 months was excellent (Fig. 4). 